\title{
THE INFLUENCE OF DEPORTATION ON THE IDENTITY OF GERMANS OF RUSSIA AND KAZAKHSTAN
}

\author{
Anna N. Blinova (a) \& Tatyana B. Smirnova (b) \& Elena A. Shlegel (c) \\ (a) Institute of Archaeology and Ethnography of the Siberian Branch of \\ the Russian Academy of Sciences. Omsk, Russia. Email: anblinova[at]mail.ru \\ (b) Dostoevsky Omsk State University | Siberian Branch Likhachev Russian Research \\ Institute for Cultural and Natural Heritage. Omsk, Russia. Email: SmirnovaTB[at]omsu.ru \\ (c) Dostoevsky Omsk State University. Omsk, Russian. Email: ShlegelEA[at]omsu.ru
}

\begin{abstract}
The deportation of the Soviet Germans in 1941 was a turning point in their ethnic history. The deportation had a big influence on the ethnic identity of the Germans and transformed it. The aim of the research is to determine the influence of the deportation of 1941 on the modern identity of the Germans in Russia and Kazakhstan. The article contains facts about the deportation, analyzes its consequences, first of all the radical change in the territorial distribution of the Germans. The central part of the article is devoted to the influence of traumatic events on the identity of the people. The empirical base of the research consists of memories collected in expeditions and archives, as well as the results of an ethnosociological survey of Germans conducted in 2020 with the support of the International Union of German Culture. The final part is dedicated to the historical memory and presentation of the deportation events in the museums of Russia and Kazakhstan. The conclusions of the research are that the events of the deportation continue influencing the ethnic identity of the Germans of Russia and Kazakhstan greatly. The cause of it is incompleteness of rehabilitation, activities of public organizations, historical memory in which deportation occupies a central place. The authors show the need to form a positive identity that generates interest in the history and culture of their own people, a sense of pride and integrity of ethnic identity.
\end{abstract}

Keywords

Russian Germans; Germans of Kazakhstan; Ethnic Identity; Deportation; the Great Patriotic War; Historical Memory

This work is licensed under a Creative Commons «Attribution» 4.0 International License 


\section{ВЛИЯНИЕ ДЕПОРТАЦИИ НА ИДЕНТИЧНОСТЬ НЕМЦЕВ РОССИИ И КАЗАХСТАНА}

\section{Блинова Анна Николаевна (a), Смирнова Татьяна Борисовна (b), Шлегель Елена Александровна (c)}

(a) Институт археологии и этнографии Сибирского отделения Российской академии наук. Омск, Россия. Email: anblinova[at]mail.ru

(b) Омский государственный университет им. Ф.М. Достоевского | Сибирский филиал Российского научно-исследовательского института культурного и природного наследия им. Д. С. Лихачёва. Омск, Россия. Email: SmirnovaTВ[at]omsu.ru

(с) Омский государственный университет им. Ф.М. Достоевского. Омск, Россия.

Email: ShlegelEA[at]omsu.ru

\section{Аннотация}

Депортация советских немцев в 1941 г. из Поволжья и других регионов европейской части СССР на восток страны была поворотным событием в их этнической истории. Депортация оказала очень большое влияние на этническую идентичность немцев и трансформировала ее. Целью исследования является определение влияния, которое депортация 1941 г. оказала на идентичность немцев, живущих сегодня в России и в Казахстане. В статье приводятся основные факты, связанные с депортацией, и анализируются ее последствия, главным из которых было перемещение огромных масс людей в восточные регионы СССР, и кардинальное изменение территориального размещения немцев. Центральная часть статьи посвящена влиянию травмирующих событий на идентичность народа. Эмпирической базой исследования стали воспоминания, собранные в экспедициях, хранящиеся в архивах, а также результаты этносоциологического опроса немцев, проведенного в 2020 г. при поддержке Международного союза немецкой культуры. Заключительная часть исследования посвящена исторической памяти, презентации событий, связанных с депортацией немцев, в музеях России и Казахстана. Выводы исследования состоят в том, что события, которые произошли 80 лет назад, продолжают оказывать большое влияние на этническую идентичность немцев, живущих сегодня в России и Казахстане. Причинами этого являются неполная реабилитация, широкое обсуждение темы депортации, деятельность общественных организаций, формирование коллективных представлений об этих событиях, исторической памяти, в которой тема депортации занимает центральное место. Авторы приходят к выводу о необходимости формирования позитивной идентичности, которая влечет за собой интерес к истории и культуре своего народа, чувство гордости и целостность этнической идентичности.

\section{Ключевые слова}

российские немцы; немцы Казахстана; этническая идентичность; депортация; Великая Отечественная война; историческая память

Это произведение доступно по лицензии Creative Commons «Attribution» («Атрибуция») 4.0 Всемирная 


\section{ВВЕДЕНИЕ}

Немецкие меньшинства есть почти во всех странах. Численность немцев в мире составляет 86 млн. чел., в Германии проживает 75 млн. немцев, остальные 11 млн. расселены по всему миру. Людей, имеющих немецкие корни, гораздо больше, но многие из них, утратив немецкий язык и этническую идентичность, почти ассимилировались и лишь помнят о своем происхождении.

Больше всего немцев (или людей немецкого происхождения), живет в США. Так, по данным переписи населения США 2010 г., 42,8 млн. чел. (15,2\% всего населения) имеет немецкое происхождение, из них 1,4 млн. чел. назвали немецкий язык родным (Национальный состав населения США, 2015). Вторая по численности группа немцев до недавнего времени находилась на территории Советского Союза: более 2 млн. человек, из них 957 тыс. в Казахстане и 842 тыс. в России (Всесоюзная перепись населения 1989 года, 2011). С распадом СССР и началом массовой эмиграции численность немцев значительно сократилась, до 120 тыс. в Казахстане и до 400 тыс. в Российской Федерации. Резкие колебания численности и изменения в расселении были характерны для российских немцев на протяжении всей их истории, что, несомненно, являлось следствием масштабных миграционных процессов. Российские немцы постоянно куда-нибудь переезжали, двигались, не случайно они сами себя называют "Volk auf dem Weg" («народ в пути»).

Это постоянное движение, переселения не могли не оказать влияние на этническую идентичность немцев, тем более, что переселения эти были не только добровольными, но и принудительными, насильственными. И если обычное переселение, обдуманный и спланированный переезд, перемещение, предпринятое этнической группой в более благоприятные условия, - оказывают очень сильное влияние на этническую идентичность и остаются надолго в памяти народа, - что говорить о насильственном переселении, внезапном и направленном в суровые края. Депортация советских немцев в 1941 г. из Поволжья и других регионов европейской части СССР в Сибирь и Казахстан была поворотным событием в их этнической истории. Такие события не забываются, рассказы о них передаются из поколения в поколение, становятся легендарными, и они, безусловно, оказывают очень большое, трансформирующее влияние на идентичность этнической группы. 
Целью исследования является определение влияния, которое депортация 1941 г. оказала на идентичность немцев, живущих сегодня в России и в Казахстане. Со времени депортации прошло 80 лет, и сегодня осталось в живых очень немного людей, которые помнят события 1941 г. Изучение воспоминаний свидетелей тех далеких событий, - но главным образом - изучение мнения об этих событиях потомков депортированных немцев, позволяет внести вклад в копилку исследований этнической идентичности.

Логика изложения заключается в последовательном анализе факторов, оказывающих наибольшее влияние на конструирование этнической идентичности. Первым таким фактором является изменение территории проживания в результате депортации. Территория как место рождения и жизни человека и его предков напрямую связаны с представлениями о Родине, прародине народа, которая занимает центральное место в этнической идентичности. Поэтому первая часть статьи посвящена кардинальному изменению территориального размещения немцев в результате депортации. Далее представлены результаты исследования влияния на идентичность травмирующих событий. Эти исследования основаны на полевых материалах, собранных в экспедициях и на результатах этносоциологического опроса немцев, живущих в разных регионах России, который был проведен в 2020 г. В заключительной части статьи представлена роль исторической памяти в формировании этнической идентичности, формы воспроизводства идентичности через представление трагических страниц истории народа в музеях России и Казахстана.

\section{ДЕПОРТАЦИЯ СОВЕТСКИХ НЕМЦЕВ}

$\mathrm{XX}$ век оставил неизгладимый след на судьбах многих народов. За относительно короткий период времени произошли такие события, как Первая мировая война, революции 1917 г., репрессии 1930-х гг., а затем и Великая Отечественная война. Все эти сюжеты в истории сопровождались огромными человеческими потерями, разрушениями семейных связей и традиционных устоев, переселением целых народов из мест их компактного проживания в отдаленные области страны.

Красной нитью через историю многих советских народов в XX веке проходит депортация. Принудительному процессу переселения и потере своих национальных автономий подверглись балкарцы, калмыки, карачаевцы, крымские татары, чеченцы, ингуши 
и немцы. Однако из всех перечисленных народов только немцы были лишены своей территориальной автономии навсегда.

Вопросам депортации поволжских немцев были посвящены работы Н.Ф. Бугая (1991, сс. 123-128), Н.Э. Вашкау (1994), В. Гердта (1996) и др. Многочисленные архивные материалы и документы опубликованы в трудах В.А. Аумана и В.Г. Чеботаревой (1993), А.А. Германа (2000) и др. Воспоминания и мемуары легли в основу книг В.Г. Фукса (1993), Г.А. Вольтера (1998), А.А. Германа и О.Ю. Силантьевой (2011) и др. Авторы в своих работах поднимают дискуссионные вопросы относительно правомерности действий советского руководства в 1940-е гг., развенчивают мифы о самом процессе переселения и о численности пострадавших, рассказывают о депортации глазами очевидцев.

Выселение поволжских немцев с территории Автономной Советской Социалистической Республики немцев Поволжья (АССР немцев Поволжья) произошло под влиянием ложных донесений в условиях неудач первых месяцев Великой Отечественной войны. Уже 3 августа 1941 г. в Ставку Верховного Главнокомандования пришла шифрограмма с донесениями о том, что немецкое население оказывает поддержку фашистским войскам, и что необходимо дать установку местным органам власти «о выселении неблагонадежных элементов» (Ерошин, 2000, сс. 447-448.). Так как руководство страны не отрицало потенциальной возможности выступления немецкого населения в качестве «пятой колонны», решение было принято незамедлительно.

Все лица немецкой национальности в количестве 446,5 тыс. человек (Герман \& Силантьева, 2011, с. 67) были депортированы с территории АССР немцев Поволжья согласно Указу Президиума Верховного Совета СССР «О переселении немцев, проживающих в районах Поволжья» от 28 августа 1941 г. (О переселении немцев, проживающих в районах Поволжья, 02.09.1941).

Именно на территории Поволжья немцы проживали компактными группами, начиная с XVIII в., после издания 22 июля 1763 г. Екатериной II Манифеста «О дозволении всем иностранцам, в Россию въезжающим, поселяться в которых Губерниях они пожелают и о дарованных им правах» (Ауман \& Чеботарева, 1993, сс. 18-21). Основными регионами, где началось формирование первых немецких колоний, стали Поволжье, Северное Причерноморье, Закавказье и окрестности столицы. Среди переселенцев были представители различных этнических групп, проживавшие в то время на обособленных землях Германии. В их число входили франконцы, баварцы, саксонцы, меннониты и многие другие этнические группы (Киссер \& Смирнова, 2017, 
сс. 44-53). Поволжье было самым крупным регионом по числу прибывающих переселенцев. За первые 10 лет колонизационной политики вблизи Саратова было основано 105 колоний (Дитц, 1997, с. 75), с численностью более 23,2 тыс. человек (Плеве, 2008, с. 171). Постепенно здесь сложилась особая этнотерриториальная группа немцев - поволжские немцы, обладающая общим этническим самосознанием. Именно немцы Поволжья приняли на себя основной удар репрессивной политики советского государства.

Данные Первой всеобщей переписи населения 1897 г. и последующих советских переписей подтверждают тот факт, что немцы преимущественно были сконцентрированы в регионе Поволжья. Так, перепись населения Российской империи 1897 г. зафиксировала 1790,5 тыс. человек, для которых немецкий язык был родным, или $1,42 \%$ от всех указавших свой родной язык (Первая всеобщая перепись населения Российской Империи 1897 г., 2005). Немцы по численности занимали восьмое место в стране среди всех национальностей. Несмотря на то, что постепенно ареал распространения немецкого населения становился все шире, основная масса немцев проживала в европейской части страны (1312,2 тыс. человек), прежде всего, в Самарской (224,3 тыс. человек) и Саратовской (166,5 тыс. человек) губерниях.

В среднеазиатских владениях Российской империи, согласно этой же переписи, числилось всего лишь чуть более 8,8 тыс. человек, говорящих на немецком языке. Это объясняется тем, что добровольное освоение Западной Сибири и Казахстана началось позже, со второй половины XIX в., когда в среде немецких крестьян обострилась проблема малоземелья. Заселению восточных областей благоприятствовало как относительно дешевая стоимость земельных участков, так и строительство Транссибирской магистрали.

Согласно переписи населения 1920 г. в стране проживало 986,6 тыс. немцев, их них на территории Автономной области немцев Поволжья числилось 442,4 тыс. человек, или $44,8 \%$ от общего числа немцев (Красильников, 1924, сс. 30-37). Немцы составили 97,7\% от всех представленных здесь национальностей.

Первая Всесоюзная перепись населения 1926 г. зафиксировала 1238,5 тыс. немцев, из них в пределах АССР немцев Поволжья проживало 379,6 тыс. человек, или 30,6\% от общего числа немцев (Всесоюзная перепись населения 17 декабря 1926 г., 1928, сс. 12-13).

Данные предвоенной переписи 1939 г. свидетельствовали о том, что в стране проживало 1427,2 тыс. немцев, из них на территории 
Республики - 366,7 тыс. человек. Чуть больше - 392,5 тыс. немцев проживало на территории Украинской ССР (Поляков, 1992, с. 67).

15 августа 1941 г. было издано первое Постановление «Об эвакуации населения из отдельных районов Крымской АССР», согласно которому «эвакуации» подлежало 51 тыс. человек в Орджоникидзевский край (Герман, Иларионова \& Плеве, 2007, с. 432). Именно такое число немцев было зафиксировано в Крымской АССР по переписи 1939 г.

26 августа 1941 г. выходит следующее Постановление «О переселении немцев из Республики немцев Поволжья, Саратовской и Сталинградской областей». В нем говорилось о том, что немецкое население численностью 70 тыс. человек следовало переселить в Красноярский край, 91 тыс. человек - в Алтайский край, 80 тыс. человек в Омскую область, 92 тыс. человек - в Новосибирскую область и 100 тыс. человек - в Казахскую ССР (Герман, 2000, сс. 229-233).

Как финальная точка в законодательном оформлении депортации, 28 августа 1941 г. издается Указ «О переселении немцев, проживающих в районах Поволжья». Позже сами немцы будут называть этот день «черным четвергом». В Указе говорилось о том, что у советского руководства имеются данные, согласно которым среди немецкого населения страны числятся шпионы и диверсанты, готовые произвести подрывы на территории Поволжья в любой момент. В Указе также говорилось, что сами жители Республики скрывают в своих кругах диверсантов, не докладывая руководству о подобных лицах, поэтому в целях предотвращения опасных действий советское руководство принимает решение о переселении немцев в указанные области (О переселении немцев, проживающих в районах Поволжья, 02.09.1941).

В Постановлении специально оговаривалось, что все немцы по прибытии должны быть обеспечены землей, жильем и скотом соразмерно потерям. Процесс переселения должен был быть организованным и контролируемым со стороны различных органов. Для этого 27 августа была издана специальная инструкция НКВД по проведению данного мероприятия (Симченко, 1992, сс. 74-79). Основные положения свидетельствовали о том, что переселению подлежали все лица немецкой национальности, производить переселение предполагалось целыми районами или колхозами, сбор жителей Республики и коллективное обсуждение вопросов переселения запрещались. С собой разрешалось брать имущество общим весом не превышающее одной тонны на семью. На каждый эшелон назначались начальник, заместитель и 
бойцы конвойных войск. Переселяемые должны были быть предупреждены о том, что им необходимо брать с собой продовольственный запас на 20 дней. Бесплатное горячее питание должно было быть организовано регулярно в специальных пунктах один раз в сутки. Кипяток, согласно Инструкции, могли выдавать два раза в день. Среди лиц, сопровождающих эшелоны, должны числиться врачи и медсестры, обеспеченные медикаментами и необходимым инструментарием.

Воспоминания очевидцев событий, опубликованные в различных материалах, свидетельствуют о том, что Инструкция чаще всего не соблюдалась (Петрова, 2010; Герман \& Силантьева, 2011; Свирина, 2018 и др.). Людей перевозили в товарных вагонах, пищу чаще всего приходилось готовить самостоятельно во время непродолжительных остановок поезда, условия для гигиенических процедур отсутствовали.

Процесс депортации проходил в период с 3 по 20 сентября 1941 г. За это время Указом «Об административном устройстве территории бывшей Республики Немцев Поволжья» от 7 сентября 1941 г. АССР немцев Поволжья была ликвидирована (Ауман \& Чеботарева, 1993, c. 163). Первые же действия показали нереальность переселения немцев целыми колхозами на новые места жительства, поэтому 12 сентября вышло еще одно Постановление «О расселении немцев Поволжья в Казахстане», по которому разрешалось вселять немцев не колхозами, а группами хозяйств от 10 и выше (Бугай \& Гонов, 2003, с. 260). По такому принципу происходило переселение во все пункты назначения.

Данные официальной статистики по количеству депортированного населения расходятся. Основные сведения хранятся в фондах Государственного архива РФ, а именно в четвертом специальном отделе МВД СССР по спецпоселенцам. По данным НКВД, в Сибирь и Казахстан из Поволжья в сентябре было направлено 188 эшелонов, в которых находилось 446,5 тыс. лиц немецкой национальности. В том числе непосредственно с территории Республики было отправлено 373,5 тыс. человек, из Саратовской области - 46,7 тыс. человек, из Сталинградской области - 26,2 тыс. человек (Герман \& Силантьева, 2011, сс. 65-67).

В Красноярский край было доставлено 79,5 тыс. человек, в Алтайский край - 80,4 тыс. человек, в Омскую область - 82,9 тыс. человек, в Новосибирскую - 88,7 тыс. человек, в Казахскую ССР - 117,7 тыс. человек. Всего с территории Поволжья на новые места прибыло 440,2 тыс. человек (Герман \& Силантьева, 2011, с. 77).

На 1 января 1942 г. общее число депортированных немцев из европейской части Советского Союза составило 856,2 тыс. человек. Из них 
799,5 тыс. прибыли в пункты назначения (Герман, Иларионова \& Плеве, 2007, с. 437), остальные по разным причинам не были доставлены. Основным местом расселения немцев оставались области Казахстана, прежде всего, Акмолинская, Семипалатинская, Северо-Казахстанская, Павлодарская, Восточно-Казахстанская, а также Сибирь.

В итоге депортации населения немцы в местах назначения стали третьим и даже вторым по численности народом после титульных наций. Так, по результатам первой послевоенной переписи населения 1959 г., всего в СССР насчитывалось 1619,6 тыс. немцев, из них в РСФСР проживало 820 тыс. человек, в Казахской ССР числилось 659,7 тыс. человек. Немцы в Казахстане стали третьей национальной группой после русских и казахов. Такая же ситуация произошла и в Красноярском крае, где немцев насчитывалось 66,7 тыс. человек. В Алтайском крае немцы с численностью 143,1 тыс. человек стали второй национальной группой после русских. Аналогичная ситуация в Новосибирской области, где теперь насчитывалось 78,8 тыс. немцев, и в Омской области, где стало 105,8 тыс. немцев (Всесоюзная перепись населения 1959 года, 2016).

Несмотря на отчеты местных органов власти о готовности принять и обеспечить немецкое население жильем и работой, немцев расселяли зачастую в непригодных для жизни условиях. Происходящее подселение к местным семьям вызывало конфоликты ввиду незнания языка и традиций других народов. Даже те, кто активно включался с первых же дней после переселения в работу колхозов, испытывали недоброжелательное отношение к себе и своим семьям. В отдаленных районах казахской степи немцы сталкивались с проблемой нехватки воды, непригодными землями для ведения сельского хозяйства, многие семьи в первые месяцы после переселения были доведены до истощения.

Несомненно, депортация стала катастрофой в истории немецкого народа. Она явилась той точкой отсчета, после которой началось постепенное размывание этнической идентичности и забвение или намеренное отрицание своих этнических особенностей. Главное негативное последствие депортации было связано с изменением характера проживания советских немцев. Если раньше немцы проживали компактно, прежде всего, на территории Республики немцев Поволжья, а также Украины, Закавказья и Сибири, то после переселения немецкое население стало проживать дисперсно, на огромных расстояниях друг от друга. Это сыграло свою большую роль в развитии 
ассимиляционных процессов и последующей миграции немцев на территорию Германии.

\section{ВЛИЯНИЕ ДЕПОРТАЦИИ НА ИДЕНТИЧНОСТЬ}

Помимо очевидных этнодемографических последствий, депортация привела к этнопсихологическим изменениям, которые надолго определили процессы в области этнической идентичности, во многом их отголоски мы наблюдаем и сегодня. Депортация, а затем мобилизация в трудовую армию и режим спецпоселения деформировали процесс самоидентификации, этнокультурной преемственности поколений, наложили отпечаток на формирование коллективной памяти.

Вопросы влияния травмирующих событий на идентичность разных народов в последнее время вызывают устойчивый интерес у ученых (Александер, 2012; Артеменко, 2018 и др.). Для нашего исследования имеют значение работы, раскрывающие механизм функционирования и трансляции «травмированной» культурной памяти (Гучинова, 2005; Стефаненко, Тумгоева \& Котова, 2017), ее собирание и хранение (Донцов \& Гончарова, 2005; Саакян \& Худовердян, 1995), рассмотрение ее как ресурса для сплочения группы (Козер, 2000). Некоторые аспекты влияния депортации на этническую историю и идентичность немецкого населения были рассмотрены в статьях Е. А. Грак (2019), Т. С. Киссер (2020), В. С. Курске (2011), И. В. Черказьяновой (2011), О. Люхтерхандта (2013) и др.

Можно согласиться с Отто Люхтерхандтом в том, что депортация и режим трудармии привели к радикальным социальным переменам и фактически сформировали современных российских немцев. Это происходило в местах вселения и ссылки, где в трудовых лагерях и спецпоселениях собирались разные немецкоговорящие группы. Только здесь оформилась общая идентичность немецкого меньшинства, которое, согласно сталинской пропаганде, считалось частью гитлеровской «пятой колонны» независимо от места жительства, социального статуса, религиозной принадлежности и даже членства в партии или комсомоле (Luchterhandt, 2013, pp. 246-247). В ситуации, когда этничность начинает определять место группы в обществе, комплекс прав и обязанностей, а его самоидентификация выходит на одно из первых мест, по мнению Н. Лебедевой, можно говорить о наличии «синдрома навязанной этничности» (1997). Этническая принадлежность человека против его воли и желания становятся чересчур значимой характеристикой бытия и сознания. Депортация и последовавшие за ней события этнической истории повлекли за собой 
появление этого синдрома у немцев России и Казахстана. Во многом он проявлялся в нежелании демонстрировать свою этническую принадлежность и ее замалчивании.

Депортированные немцы оказались разбросаны по огромной территории Сибири и Казахстана, компактность проживания почти везде была нарушена. Переселенцы попадали в разные условия и окружение, к которым в короткий срок необходимо было адаптироваться. Некоторым повезло, - они были вселены в немецкие поселки, им было несколько легче принять новую ситуацию. Например, А. К. Вормсбехер, депортированный из Поволжья в село Александровку (старейший немецкий населенный пункт в Омской области), пишет в своей книге, что здесь они «обрели вторую родину» и судьба у нас стала общая (1993, с. 177). Но так было не у всех... Местное население в большинстве своем было негативно настроено к вновь прибывшим, считая их «фашистами». Люди оказались на грани выживания без запасов еды и теплой одежды. Многие были вынуждены обменивать личные вещи на продукты; наниматься на любую работу, получая за нее немного продуктов для поддержания сил. Из воспоминаний, собранных в этнографических экспедициях, можно сделать вывод, что самым трудным был 1942 год, «...сразу после депортации, работали у местных, за это нам давали молоко и мерзлую картошку, потом варили патоку для русских за мешок свеклы или килограмм любого зерна». Другой пример: «Во время войны жили бедно, был голод. Не было собственного дома, копали землю и за это нам разрешали жить в комнате» (Блинова, 2011, с. 357).

Немцы, прибывшие в Казахстан, в своих воспоминаниях отмечают чуть большую помощь местного населения: «выброшенные в зимнюю степь немцы были бы обречены на гибель, если бы не помощь казахов, которые разбирали немецкие семьи по домам и содержали по два-три года». О помощи казахского населения всегда вспоминал известный казахстанский литератор Г. Бельгер, называвший себя «казахом из рода атыгай» (Казиев, 2015, с. 134). Еще один пример, из дневников О.П. Шрейдер: «Нас депортировали в Казахстан, аул Баканас. Жили очень бедно. Дети, эти маленькие страдальцы, сами находили себе работу, чтобы выжить. Они брали веревки, собирали саксаул, вязали из него снопы и приносили в аул казашкам, которые их кормили» (Блинова \& Чернова, 2009, с. 195). Несмотря на тяготы, немецкое население продемонстрировало высокий уровень приспособляемости к новым условиям, заслужило уважение местного населения своим трудолюбием и бесконфликтностью. 
Депортация разобщила многие семьи, родственники терялись и умирали в дороге, были распределены по разным населенным пунктам. Мобилизация в трудовую армию усугубила ситуацию. Многие дети остались на попечении старшего поколения семьи (бабушек и дедушек), в доме которых собирались и жили все не мобилизованные члены семьи. В связи с этим изменяются агенты социализации ребенка; если раньше основное место занимала мать, то в этот период эта роль переходит в основном к бабушкам. Часто обязанность заботы о младших братьях и сестрах ложилась на плечи старшего ребенка в семъе. Все это изменило процесс трансляции этнокультурной информации, многие элементы просто выпали из него либо упростились и обеднели.

Новые условия заставили немцев отказаться от родного языка, как основного «этнодемонстрирующего» признака. Именно депортация запустила интенсивные этноязыковые процессы, которые привели к слабому владению немецким языком современными поколениями и фактической утрате диалектных форм языка. Многим немцам в короткие сроки пришлось освоить русский (а в Казахстане, кроме русского, и казахский) язык, при этом немецкий остался языком семейного общения и религиозных собраний.

Одним из последствий депортационной политики стали изменения в религиозной сфере. Высокая степень религиозности немцев не позволила им полностью отказаться от своих взглядов, хотя их скрывали. При этом традиции протестантских общин, их автономность и самодостаточность в обрядовых и вероисповедальных вопросах, масса самодеятельных проповедников и толкователей Библии объясняют сохранность этого элемента духовной культуры (Кригер, 1999, с. 84). При депортации семьи взяли с собой Библии, которые сейчас хранятся как семейные реликвии. Для многих именно вера стала источником сил и надежд в этот период. Реальностью стало замыкание религиозности в семье, в узком кругу родственников, друзей и соседей.

Низкий общественный статус этнической группы приводил к желанию изменить свое положение, в том числе с помощью смены фамилии (см. Киссер, 2020) и межэтнических браков. Уже в 1945 г. доля национально-смешанных браков в сельских населенных пунктах Омской области составляла 52,5\% от всех заключенных браков (а у городского населения этот показатель был еще выше), и в последующие периоды постоянно росла (Смирнова, 2005, с. 204). При этом национальность детей в таких семьях практически всегда указывалась 
не немецкая. Эти процессы также привели к усложнению процесса этнического самоопределения.

Депортация имела и отложенный эффект. Сегодня травматические страницы этнической истории немецкого населения являются важным элементом культурной памяти народа и инструментом для его этнической идентификации. В 2020 г. был проведен этносоциологический опрос немцев, живущих в Российской Федерации. Темой опроса было современное состояние идентичности, языка и культуры. Всего была опрошена 1 тыс. чел. Этносоциологический опрос проводился во всех 8 федеральных округах России, от Калининграда до Владивостока, в 200 населенных пунктах, от крупных мегаполисов до небольших деревень. Широкий территориальный охват, в сочетании с соблюдением пропорций в расселении и численности немцев по регионам России, подтверждает репрезентативность полученных данных. По данным опроса, история играет роль консолидирующего фактора. Так, на вопрос «Что, по-Вашему, объединяет немцев, живущих в России?» 54,7\% респондентов сказали, что главным объединяющим признаком является именно общая историческая судьба (почти столько же - 55,3\% назвали общую культуру, на третьем месте по значимости находится немецкий язык - 48,1\%).

Ключевым моментом в истории депортация является до настоящего времени, об этом свидетельствуют ответы на вопрос о наиболее важных датах. 66,9\% респондентов назвали даты в истории, которые считают важными, 33,1\% - затруднились ответить. Из ответивших положительно 73,7\% назвали важнейшей датой 28 августа 1941 г., когда вышел указ о депортации немцев Поволжья. Многие респонденты не указывали точную дату, но писали просто «депортация», «выселение поволжских немцев в Сибирь», «ликвидация Республики немцев Поволжья». Так или иначе, о депортации знают все немцы, поскольку все они являются либо потомками депортированных, либо мобилизованных в «трудармию». Можно сказать, что в коллективной памяти российских немцев преобладают даты, связанные с трагическими, драматическими событиями.

На втором месте по значимости - Манифест Екатерины II о приглашении иностранцев в Россию. Среди других важнейших дат назывались организация АССР немцев Поволжья, указы о частичной реабилитации 1955, 1964 и 1972 гг., движение за восстановление республики 1988-1992 гг. На наш взгляд, для формирования позитивной идентичности необходимо распространение информации не только о трагедии немецкого народа, но и о вкладе немцев в отече- 
ственную историю и культуру, о выдающихся достижениях в области экономики, культуры, науки, об успешном преодолении негативных последствий правовой и политической дискриминации. Преодоление образа «народа-жертвы» будет способствовать развитию нормальных, гармоничных отношений с другими народами. Пока же тема депортации и ликвидации республики занимает центральное место в историческом дискурсе.

Большую роль в трансляции культурной памяти играет семья. Устные истории несут в себе часть эмоционального наследия семьи и оказывают влияние на стиль воспитания детей, семейный уклад и жизненные установки ее членов. Через них происходит формирование семейной идентичности, а затем и приобщение к историческому прошлому народа в целом (Стефаненко, Тумгоева \& Котова, 2017, c. 48). Культурная память фрагментарна, избирательна, эмоционально насыщена. Она чаще всего передается не линейно: часто от дедов к внукам, минуя родителей (Хальбвакс, 2005). Нежелание рассказывать о пережитой трагедии объясняется тем, что для травматической памяти, которой стала память о депортации у современников тех событий, характерно предание ее забвению. Заботясь о детях, немцы ограждали их от этих эпизодов семейной и этнической истории, но со временем эмоциональный накал и психологическая напряженность ослабевает, и пережитой трагедией уже можно поделиться.

Кроме того, от поколения к поколению изменяется ее фокус; если у людей, переживших событие, она сфокусирована на его значении для себя, то следующие поколения ориентируются на его политическое и этноисторическое значение (Стефаненко, Тумгоева \& Котова, 2017, c. 49). Для народа культурная память - это общие представления о прошлом, выражающиеся в миффах, традициях, воспоминаниях, которые группа разделяет, принимает и транслирует.

\section{ПАМЯТЬ О ДЕПОРТАЦИИ В МУЗЕЯХ}

С течением времени процесс коммеморации с семейного уровня переходит на общегрупповой, основными инструментами трансляции культурной памяти становятся институты и места памяти. Музей один из инструментов формирования и поддержания культурной памяти, работающий с индивидуальными воспоминаниями и жизненным опытом посетителя, предлагая определенное переживание и аффективное отношение к увиденному.

В России и Казахстане существует довольно много музеев, в коллекциях которых представлены материалы по истории и 
культуре немецкого населения. Омская, Новосибирская области и Алтайский край - это территории добровольной колонизации, соответственно, тема переселения и адаптации, устройства на новом месте занимает центральное место в музейных собраниях. В основном их экспозиции представляют собой реконструкцию немецкого жилища второй половины XX века. Однако трагические страницы этнической истории тоже представлены в виде стендов со списками мобилизованных в трудовую армию, альбомами, фотографиями, справками о реабилитации.

Многие музейные работники отмечают сложность сбора экспонатов по этой теме; остались лишь единичные предметы, но они сегодня имеют символическое значение, как для семей, передавших их музею, так и для самого музея. Например, в школьном музее с. Цветнополье Омской области это тетрадь-песенник М.Д. Майер с записанными текстами бытовых и лирических песен, популярных в 1948-1949 гг., и трудармейским фольклором. Записи сделаны в Ухте в Комилаге на немецком и русском языках. Первая запись - песня "Das Leben im 3 Barak” («Жизнь в 3 бараке») - носит билингвальный характер, насыщена бытовыми подробностями жизни в экстремальных условиях. В школьном музее с. Гришковка хранятся библии, семейный альбом, вязаный гольфик и вилка, привезенные с Волги. Детские гольфики когда-то, еще до войны, были заботливо связаны бабушкой своему внуку Гергарду. На момент депортации ему было уже 15 лет, и его мама, собирая детские вещи, сложила и их - в семье были еще и младшие дети. Остался только один гольфик, но Гергард не мог с ним расстаться, так как в нем заключены все чувства, эмоции, воспоминания о его счастливом, беззаботном детстве. Уже потомки семьи передали в музей этот предмет. Вилка тоже имеет свою легенду. Отец, собирая сына в трудовую армию, велел взять что-то с собой из дома, что напоминало бы ему семью. Сын взял с собой свою вилочку из столового набора, привезенного еще с Волги. А когда вернулся домой из трудовой армии, достал эту вилочку и положил в буфет со словами: «Вот, теперь я дома».

Первая узкоспециализированная выставка «Депортация» была открыта в декабре 2000 г. в Омском государственном историко-краеведческом музее. Материалы для нее собирались во время экспедиционных выездов в районы Омской области и Северо-Казахстанскую область Республики Казахстан. Всего было собрано более 600 экспонатов. Выставка состояла из трех разделов: «Депортация», «Спецпоселение» и «Реабилитация», она включала в себя карты, документы, 
фотографии и личные вещи. Хотя выставка была посвящена всем депортированным народам, но несколько большее внимание в ней отводилось российским немцам как основному «контингенту», депортированному в Омскую область и северный Казахстан. Выставка имела большую популярность и стала точкой отсчета для формирования коллекций по этой теме в музее. Затем музей еще не раз готовил подобные выставки (Баах, Вибе \& Пьянова, 2001). Последний проект Омского государственного историко-краеведческого музея приурочен к 80-летию депортации - это издание альбома, посвященного творчеству Александра Вормсбехера. Это рассказ о трагической судьбе российских немцев в годы Великой Отечественной войны, воспринятой через призму творчества и биографию самодеятельного художника. Его серия акварельных рисунков, названная «Летопись семьи Вормсбехер в рисунках и документах», дает возможность проследить все горестные этапы судьбы российских немцев: депортация, мобилизация в трудовую армию, спецкомендатура и т.д. Он написал их в 1993, а в 1994 году передал в Омский государственный историко-краеведческий музей. Именно эта коллекция стала основой нового альбома.

Территории Томской, Кемеровской областей и Красноярского края стали местом вселения депортированного немецкого населения, трудмобилизации и спецпоселения, что нашло отражение и в музейных экспозициях. Так, «немецкая тема» в Анжеро-Судженском городском краеведческом музее представлена в постоянной экспозиции разделом по истории депортаций. В нем рассказывается о судьбах спецпоселенцев через современные фотографии бывших лагерных объектов, предметы, обнаруженные на местах дислокации лагпунктов АнжероСудженского отделения Севкузбасслага, фрагменты воспоминаний и биографические материалы заключенных. Подобные разделы есть в краеведческом музее г. Юрги (Кемеровская область), музее с. Колыон (Кемеровская область), музее истории и культуры с. Александровское (Томская область), школьном музее Балахтонской средней общеобразовательной школы (Красноярский край), Таймырском окружном краеведческом музее (Красноярский край).

В Томском областном краеведческом музее им. М. Б. Шатилова с 2013 г. реализуется проект «Сибиряки вольные и невольные». Это интернет-ресурс, на котором представлены материалы по проблеме формирования населения Сибири и Дальнего Востока. Здесь размещены специальные исследования по теме, краеведческие очерки, истории населенных пунктов и истории семей сибиряков, в том числе и российских немцев. Например, «Советские немцы - 
“наказанный народ”». Интервью с Флорентиной Зауэр. 1996 год» (Яковлев, 2020). Подобные материалы содержит коллекция Томского мемориального музея «Следственная тюрьма НКВД». В ходе реализации проектов «Последний свидетель» и «Сибирские “спецы”» были собраны рассказы людей, подвергшихся репрессиям, в том числе и воспоминания российских немцев (Мемориальный музей «Следственная тюрьма НКВД», 2020).

В 2009 г. в Кемеровской области был создан Музей-заповедник «Трехречье», состоящий их двух частей: музейно-мемориального комплекса «ГУЛАГ» и археолого-этнографического комплекса «УстьПызас». Мемориальная экспозиция «Шорский ГУЛАГ» посвящена памяти жертв репрессий (среди которых было немало советских немцев). Это экспозиция под открытым небом в виде типового лесозаготовительного лагеря 1930-1950-х гг. Его территория обнесена двойной линией заграждения: высоким деревянным забором и линией колючей проволоки, образующей запретную зону со смотровыми вышками. В музее создана постоянно действующая экспозиция, посвященная российским немцам «Время испытаний и годы надежд». Большая часть экспозиции относится к периоду депортации, трудовой армии и жизни советских немцев в Кузбассе. На выставке, кроме архивных документов и стендов, представлены личные вещи трудармейцев и членов их семей, воспоминания и документы из семейных архивов.

Музеи являются местом, где актуализируется этническая идентичность российских немцев, их пространство используется не только как выставочное или экспозиционное. Например, в Музее истории, культуры и религии российских немцев при Центре немецкой культуры г. Ухты показывают спектакли о судьбе и истории российских немцев. Одним из последних был спектакль «Память - мой злой властелин», посвященный депортации немецкого населения на Урал (Киссер, 2018, с. 278).

В музеях Казахстана тема переселения советских немцев представлена в контексте общего депортационного процесса в СССР. Специализированную работу по сбору материалов по этой теме проводит Музей памяти жертв политических репрессий поселка Долинка (Музей Карлага). В музеях Алматы, Нур-Султана, Усть-Каменогорска также подготовлено несколько выставок, посвященных насильственному переселению народов, в том числе и немцев.

Негативный опыт, приобретенный немцами в 1941-1955 гг., скорбь и трагедии, пережитые народом, во многом стали объединя- 
ющей силой, частью культурной памяти и средством этнической идентификации. Музеи в этом процессе сыграли не последнюю роль. Масштабные мероприятия были проведены в разные годовщины депортации: созданы десятки экспозиций и выставок, повсеместно и регулярно проходят дни памяти и скорби жертв репрессий, издаются воспоминания. Создана электронная книга памяти, с указанием «мест памяти» - карты, некрополи, памятные знаки.

\section{ВЫВОДЫ}

Проведенное исследование позволяет утверждать, что депортация советских немцев в 1941 г. из европейской части в СССР в Сибирь и Казахстан продолжает оказывать очень большое влияние на этническую идентичность немцев, живущих сегодня в России и Казахстане. Возможно, сегодня это влияние даже больше, чем сразу после депортации или в советское время. Причин этому несколько.

Во-первых, депортация коснулась каждой семьи, каждого немца. Тотальная этническая чистка территории, выселение всех, кто был немцем, без исключения, даже состоявших в смешанных браках, привели к тому, что сегодня все, кто имеет немецкие корни, имеет и депортированных родственников. Те немцы, которые жили в Сибири и Казахстане до 1941 г., были мобилизованы в «трудармию», находились на спецпоселении, то есть также подверглись репрессиям. В результате очень разных по возрасту, образованию, профессии, социальному статусу, взглядам и убеждениям людей объединяет история их родители, дедушки и бабушки были депортированы и репрессированы.

Во-вторых, эта тема стала достоянием общественности. Запрет на обсуждение темы сталинских репрессий в середине 1980-х гг. сменился форсированными исследованиями. К настоящему времени вышли монографии, сборники материалов конференций, статьи, в которых тема депортации советских немцев изучена достаточно полно. Помимо научных изданий, есть учебники для национальнокультурных центров, документальные и художественные фильмы, художественные произведения, например, широко известные романы Гузель Яхиной «Дети мои». Все немецкие общественные организации отмечают День памяти и скорби - 28 августа. Деятельность ученых, писателей, художников, общественных лидеров привела к широкому обсуждению темы депортации и формированию коллективных представлений об этих событиях. Множество личных семейных историй 
слились в коллективные представления об исторических событиях, которые принято называть исторической памятью.

В-третьих, тема депортации приобрела особую остроту в связи с неполной реабилитацией немцев. «Закон о реабилитации репрессированных народов», принятый в 1991 г., не был полностью выполнен, в частности, его положение о восстановлении национально-государственных образований, сложившихся до их упразднения (статьи 3, 5, 6). Отказ от восстановления АССР немцев Поволжья не только подхлестнул эмиграцию немцев в Германию, но и негативно сказался на идентичности российских немцев. Вопрос «за что наказывают наш народ?» и подобные тому продолжали множиться, поскольку немцы были единственным депортированным народом, которому обвинения в коллаборационизме нельзя было выдвинуть даже теоретически (депортация была превентивной), и продолжали оставаться единственным в России народом, чья территориальная автономия не была восстановлена. В результате постоянного ущемления прав народа его идентичность тоже начинает приобретать ущемленный характер. Предпринимаемые сегодня немецким общественным движением усилия по формированию позитивной этнической идентичности сталкиваются с укоренившимися мнениями о том, что немцы постоянно подвергались дискриминации. Приводимые в качестве успешного примера десятки немецких фамилий (включая Германа Греффа и Алексея Миллера) конкурируют с аргументами «мой отец (или другие родственники) не смог поступить в институт и занять хорошую должность из-за своей национальности». Доводы о том, что физические потери среди депортированных были ниже, чем среди тех, кто воевал на фронте, наталкиваются на мнение о том, что «не позволить немцам сражаться с фашизмом - это была самая большая несправедливость по отношению к нашему народу». Это слово «несправедливость» являлось ключевым в формировании негативной и ущемленной идентичности.

В-четвертых, сыграла свою роль в актуализации идентичности помощь Германии, включая возможность эмиграции, в большей степени оказываемой тем немцам, которые (или предки которых) пострадали от депортации и ее последствий.

\section{БЛАГОДАРНОСТИ}

Исследование выполнено при финансовой поддержке РФФИ в рамках проекта проведения научных исследований «Этническая 
идентичность на постсоветском пространстве (на примере немцев России, Украины и Казахстана)», проект № 20-09-00 177.

\section{Список литературы}

Herdt, V. (1996). Deportation, Sondersiedlung, Arbeitsarmee: Deutsche in der Sowjetunion 1941 bis 1956 [Deportation, Special Settlement, Labor Army: Germans in the Soviet Union 1941 to 1956]. Köln: Verlag Wissenschaft und Politik. (In German).

Luchterhandt, O. (2013). Die Russlanddeutschen, eine traumatisierte Volksgruppe - Herausforderung für ihre Integration in Deutschland [The Russian Germans, a traumatized ethnic group-Challenge for their integration in Germany]. In Deportationen in Stalins Sowjetunion. Das Schicksal der Russlanddeutschen und anderer Nationalitäten. XXI. [Deportations in Stalin's Soviet Union. The Fate of the Russian Germans and Other Nationalities. XXI.] (pp. 238-256). Lüneburg: Institut Nordostdeutsches Kulturwerk. (In German).

Александер, Дж., \& Куракин, Д. Ю. (2012). Культурная травма и коллективная идентичность. Социологический журнал, (3), 5-40.

Артеменко, Н. А. (2018). Время, память, травма: Между бытием и небытием. Studia Culturae, (36), 124-136.

Ауман, В. А., \& Чеботарева, В. Г. (1993). История российских немцев в документах, 1763-1992 г2. Москва: Международный институт гуманитарных программ.

Баах, С. В., Вибе, П. П., \& Пьянова, О. В. (2001). Формирование коллекции и создание выставки «Депортация» в Омском государственном историко-краеведческом музее. В Немцы СССР в годы Великой Отечественной войны и в первое послевоенное десятилетие, 1941-1955 г2. (сс. 548-555). Москва: Готика.

Блинова, А. Н. (2011). Память о трагическом прошлом, ее сохранение и трансфорормация в поколениях семей этнических немцев Западной Сибири.

В Гражданская идентичность и внутренний мир российских немщев в годь Великой Отечественной войны и в исторической памяти потомков (сс. 355-359). Москва: МСНК-пресс.

Блинова, А. Н., \& Чернова, И. Н. (2009). Этнография семьи и детства немецкого населения Западной Сибири в XX - начале XXI века. Омск: ООО Издательский дом «Наука».

Бугай, Н. Ф. (1991). Депортация. Берия докладывает Сталину. Коммунист, (3), 123-128.

Бугай, Н. Ф., \& Гонов, А. М. (2003). По решению Правительства Союза ССР. Нальчик: Издательский центр «Эль-Фа».

Вашкау, Н. Э. (1994). Немцы в России: История и судьба. Волгоград: Издательство Волгоградского государственного университета.

Вольтер, Г. А. (1998). Зона полного покоя: Российские немцы в годы войны и после неё. Москва: Варяг. 
Вормсбехер, А. (1993). В сибирской глубинке. Москва: Септима.

Всесоюзная перепись населения 17 декабря 1926 г.: Краткие сводки. Народность и родной язык населения СССР. (1928). Москва: ЦСУ СССР.

Всесоюзная перепись населения 1959 года. Национальный состав населения по регионам России. (2016). Извлечено от Демоскоп Weekly website: http:// www.demoscope.ru/weekly/ssp/rus_nac_59.php?reg=50

Всесоюзная перепись населения 1989 года. Национальный состав населения по республикам СССР. (2011, июнь 4). Извлечено от Демоскоп Weekly website: http://www.demoscope.ru/weekly/ssp/sng_nac_89.php?reg=0

Герман, А. А. (2000). История Республики немщев Поволжья в событиях, фактах, документах. Москва: Готика.

Герман, А. А., Иларионова, Т. С., \& Плеве, И. Р. (2007). История немщев России. Москва: МСНК-пресс.

Грак, Е. А. (2019). Память о депортации как фактор этнической идентичности (на примере немцев Красноярского края). Ежегодник Международной ассоциащии исследователей истории и культуры российских немцев, (2), 114-123. doi: 10.33466/2500-0063-2019-6-2-114-123

Гучинова, Э. М. (2005). Помнить нельзя забыть: Антропология депортационной травмы калмыков. Stuttgart: Ibidem Press.

Дитц, Я. Е. (1997). История поволжских немцев-колонистов. Москва: Готика.

Донцов, А. И., \& Гончарова, В. А. (2005). Холокост как феномен социальной памяти. Век толерантности: научно-публицистический вестник, (1-2), 55-71.

Ерошин, В. П. (2000). Органы государственной безопасности в Великой Отечественной войне: Сборник документов (Т. 2). Москва: Русь.

Казиев, С. Ш. (2015). Стратегии адаптации «Наказанных» народов и местное население в Казахстане (1941-1953 гг.). Известия Алтайского государственного университета, (4), 133-137. doi: 10.14258/izvasu(2015)4.1-20

Киссер, Т. С. (2018). Советские немцы в трудармии на Урале: Факторы формирования лагерной идентичности. Вестник Омского университета. Серия Исторические науки, (2), 270-279. doi: 10.25513/2312-1300.2018.2.270-279

Киссер, Т. С. (2020). Негативная идентичность российских немцев. Вестник Омского университета. Серия «Исторические науки», 7(3), 112-122. doi: 10.24147/23121300.2020.7(3).112-122

Козер, Л. (2000). Функции социального конфликта. Москва: Идея-Пресс, Дом интеллектуальной книги.

Красильников, М. (Ред.). (1924). Сборник статистических сведений по Союзу С.С.Р. 1918-1923. Москва.

Кригер, В. (1999). Особенности кадровой политики государства в отношении российских немцев в советский период. В Культура немцев Казахстана: История и современность (сс. 68-93). Алматы. 
Курске, В. С. (2011). Множественная этническая идентичность: Теоретические подходы и методология исследования (на примере российских немщев) (Диссертация на соискание ученой степени кандидата наук). Московский государственный институт Международных отношений, Москва.

Лебедева, Н. М. (1997). «Синдром навязанной этничности» и способы его преодоления. Этническая психология и общество, 104-115.

Мемориальный музей «Следственная тюрьма НКВД». (2020). Извлечено от Проекты website: https://nkvd.tomsk.ru/projects/

Национальный состав населения США (перепись 2010). Расовый состав. Афроамериканцы, немцы. (2015, апрель 25). Извлечено от Statdata.ru website: http:// www.statdata.ru/nacionalnyj-sostav-usa

О переселении немцев, проживающих в районах Поволжья. (1941, сентябрь 2). Газета «Ведомости Верховного Совета СССР». Извлечено от https:// naukaprava.ru/catalog/1/127/12 701/68 818?view=1

Первая всеобщая перепись населения Российской Империи 1897 г. Распределение населения по родному языку, губерниям и областям. (2005). Извлечено от Демоскоп Weekly website: http://www.demoscope.ru/weekly/ssp/ rus_lan_97.php?reg=0

Петрова, Г. П. (2010). Невыбранное время, нежданная судьба. Воспоминания российских немцев г. Котласа и Котласского района. Котлас.

Плеве, И. Р. (2008). Немещкие колонии на Волге во второй половине ХVII века. Москва: МСНК-пресс.

Поляков, Ю. А. (Ред.). (1992). Всесоюзная перепись населения 1939 года: Основные итоги. Москва: Наука.

Свирина, Д. В. (2018). Воспоминания о депортации поволжских немцев: Основной нарратив и мотивы (на материалах Красноярского края). Вестник Томского государственного университета, (51), 157-163. doi: 10.17223/19988613/51/22

Симченко, Ю. Б. (Ред.). (1992). Депортащии народов СССР (1930-1950-е годы). Документальные источники Центрального государственного архива Октябрьской Революции, высших органов государственной власти и органов государственного управления (ЦГАОР) СССР. Часть 1. Москва.

Смирнова, Т. Б. (2005). Межэтнические процессы у российских немцев Западной Сибири. В Российские немщы в инонациональном окружении: Проблемы адаптации, взаимовлияния, толерантности (сс. 203-212). Москва: МСНК-пресс.

Смирнова, Т. Б., \& Киссер, Т. С. (2017). Многообразие немцев России. Уральский Исторический Вестник, (2), 44-53.

Стефаненко, Т. Г., Тумгоева, Т. А., \& Котова, М. В. (2017). Культурная память и социальная идентичность ингушей как представителей репрессированного народа. Национальный психологический журнал, (4), 45-56. doi: 10.11621/ npj.2017.0404 
Фукс, В. Г. (1993). Роковые дороги поволжских немцев, 1763-1993 г2.: Исторические факты. Документы. Обращения к властям. Письма. Воспоминания лии преследуемого народа. Красноярск.

Хальбвакс, М. (2005). Коллективная и историческая память. Неприкосновенньй запас, 2(2-3), 2-27.

Худавердян, К. С. (1995). Геноцид армян: Сквозь призму десятилетий. Ереван.

Черказьянова, И. В. (2011). Депортация российских немцев: Психологические последствия и влияние на гражданскую идентичность и внутренний мир. В Гражданская идентичность и внутренний мир российских немцев в годы Великой Отечественной войны и в исторической памяти потомков (сс. 77-88). Москва: МСНК-пресс.

Яковлев, Я. А. (2020, март 3). Советские немцы - «наказанный народ» (типичная судьба сибирской немки Флорентины Зауэр). Часть 1. Извлечено от Сибиряки вольные и невольные website: https://xn--90anbaj9ad0j.xn--80asehdb/ documents/sovetskie-nemcy-nakazannyj-narod-tipichnaya-sudba-sibirskoj-nemkiflorentiny-zauer-chast-1/

\section{References}

Alexander, J., \& Kurakin, D. Y. (2012). Cultural Trauma and Collective Identity. Sociological Journal, (3), 5-40. (In Russian).

All-Union Population Census of 1959. Ethnic composition of the population by region of Russia. (2016). Retrieved from Demoscope Weekly website: http://www.demoscope.ru/weekly/ssp/rus_nac_59.php?reg=50 (In Russian).

All-Union Population Census of December 17, 1926: Brief summaries. Nationality and native language of the USSR population. (1928). Moscow: Central Statistical Bureau of the USSR. (In Russian).

Artemenko, N. A. (2018). Time, Memory, Trauma: Between Being and Nonexistence. Studia Culturae, (36), 124-136. (In Russian).

Auman, V. A., \& Chebotareva, V. G. (1993). History of Russian Germans in Documents, 1763- 1992. Moscow: International Institute for Humanitarian Programs. (In Russian).

Baakh, S. V., Wiebe, P. P., \& Pyanova, O. V. (2001). Formation of the collection and the creation of the exhibition "Deportation" at the Omsk State Museum of History and Regional Studies. In Germans in the USSR during the Great War and the first postwar decade, 1941-1955 (pp. 548-555). Moscow: Gothic. (In Russian).

Blinova, A. N. (2011). Memory of the Tragic Past, its Preservation and Transformation in the Generations of Ethnic German Families of Western Siberia. In Civic identity and the inner world of Russian Germans during the Great War and in the historical memory of descendants (cc. 355-359). Moscow: MSNK-Press. (In Russian). 
Blinova, A. N., \& Chernova, I. N. (2009). Ethnography of Family and Childhood of the German Population of Western Siberia in the 20th and Early 21st Centuries. Omsk: Nauka Publishing House LLC. (In Russian).

Bugai, N. F. (1991). Deportation. Beria reports to Stalin. The Communist, (3), 123-128. (In Russian).

Bugai, N. F., \& Gonov, A. M. (2003). By decision of the Government of the Union of Soviet Socialist Republics. Nalchik: El-Fa Publishing Center. (In Russian).

Cherkazyanova, I. V. (2011). The Deportation of Russian Germans: Psychological Consequences and Influences on Civic Identity and the Internal World. In Civic identity and the inner world of Russian Germans during the Great War and in the historical memory of descendants (pp. 77-88). Moscow: MSNK-Press. (In Russian).

Dietz, J. E. (1997). History of the Volga German Colonists. Moscow: Gothic.. (In Russian).

Dontsov, A. I., \& Goncharova, V. A. (2005). The Holocaust as a phenomenon of social memory. The Age of Tolerance: A Scientific and Publicistic Bulletin, (1-2), 55-71. (In Russian).

Eroshin, V. P. (2000). State Security Agencies in the Great War: Collection of Documents (Vol. 2). Moscow: Rus. (In Russian).

Fuks, V. G.(1993). The Fatal Roads of the Volga Germans, 1763-1993: Historical Facts. Documents. Appeals to the authorities. Letters. Memories of Persecuted People. Krasnoyarsk. (In Russian).

Grack, E. A. (2019). Memory of Deportation as a Factor of Ethnic Identity (Case Study of Germans of Krasnoyarsk Region). Yearbook of the International Association of Researchers of History and Culture of Russian Germans, (2), 114-123. doi: 10.33466/2500-0063-2019-6-2-114-123 (In Russian).

Guchinova, E. M. (2005). Remembering cannot be forgotten: The Anthropology of the Deportation Trauma of the Kalmyks. Stuttgart: Ibidem Press. (In Russian).

Halbwachs, M. (2005). Collective and historical memory. Untouchable supply, 2(2-3), 2-27. (In Russian).

Herdt, V. (1996). Deportation, Sondersiedlung, Arbeitsarmee: Deutsche in der Sowjetunion 1941 bis 1956 [Deportation, Special Settlement, Labor Army: Germans in the Soviet Union 1941 to 1956]. Köln: Verlag Wissenschaft und Politik. (In German).

Herman, A. A. (2000). History of the Volga Germans in events, facts, documents. Moscow: Gothic. (In Russian).

Herman, A. A., Hilarionova, T. S., \& Pleve, I. R. (2007). History of the Germans of Russia. Moscow: MSNK-press.. (In Russian).

Kaziev, S. Sh. (2015). Adaptation Strategies of the "Punished" Peoples and the Local Population in Kazakhstan (1941-1953). Proceedings of the Altai State University, (4), 133-137. doi: 10.14258/izvasu(2015)4.1-20 (In Russian).

Khudaverdyan, K. S. (1995). The Armenian Genocide: Through the Prism of Decades. Yerevan. (In Russian). 
Kisser, T. S. (2018). Soviet Germans in the Labor Army in the Urals: Factors of Camp Identity Formation. Bulletin of Omsk University. Historical Studies Series, (2), 270-279. doi: 10.25513/2312-1300.2018.2.270-279 (In Russian).

Kisser, T. S. (2020). The Negative Identity of Russian Germans. Bulletin of Omsk University. Series "Historical Sciences”, 7(3), 112-122. doi: 10.24147/2312-1300.2020.7(3).112-122 (In Russian).

Koser, L. (2000). Functions of Social Conflict. Moscow: Idea-Press, House of Intellectual Book. (In Russian).

Krasilnikov, M. (Ed.). (1924). Collection of statistical data on the USSR. 1918-1923. Moscow. (In Russian).

Krieger, V. (1999). Peculiarities of the State Personnel Policy for Russian Germans in the Soviet Period. In German Culture in Kazakhstan: History and Modernity (pp. 68-93). Almaty. (In Russian).

Kurske, V. S. (2011). Multiple Ethnic Identities: Theoretical Approaches and Research Methodology (Case Study of Russian Germans) (PhD thesis). Moscow State Institute of International Relations, Moscow. (In Russian).

Lebedeva, N. M. (1997). "The Syndrome of Imposed Ethnicity" and Ways of Overcoming it. Ethnic Psychology and Society, 104-115. (In Russian).

Luchterhandt, O. (2013). Die Russlanddeutschen, eine traumatisierte Volksgruppe - Herausforderung für ihre Integration in Deutschland [The Russian Germans, a traumatized ethnic group-Challenge for their integration in Germany]. In Deportationen in Stalins Sowjetunion. Das Schicksal der Russlanddeutschen und anderer Nationalitäten. XXI. [Deportations in Stalin's Soviet Union. The Fate of the Russian Germans and Other Nationalities. XXI.] (pp. 238-256). Lüneburg: Institut Nordostdeutsches Kulturwerk. (In German).

National composition of the U.S. population (2010 Census). Racial composition. African Americans, Germans. (2015, April 25). Retrieved from Statdata.ru website: http:// www.statdata.ru/nacionalnyj-sostav-usa (In Russian).

NKVD Investigation Prison Memorial Museum. (2020). Retrieved from Projects website: https://nkvd.tomsk.ru/projects/ (In Russian).

On the resettlement of Germans living in areas of the Volga region. (1941, September 2). The newspaper "Bulletin of the Supreme Soviet of the USSR". Retrieved from https:// naukaprava.ru/catalog/1/127/12 701/68 818?view=1 (In Russian).

Petrova, G. P. (2010). Unchosen Time, Unexpected Fate. Memoirs of the Russian Germans from the town of Kotlas and the Kotlas area. Kotlas. (In Russian).

Pleve, I. R. (2008). German Colonies on the Volga River in the Second Half of the 18th Century. Moscow: MSNK-press. (In Russian).

Polyakov, Y. A. (Ed.). (1992). All-Union census of the population 1939: Main results. Moscow: Nauka. (In Russian). 
Simchenko, Y. B. (Ed.). (1992). Deportations of the USSR Peoples (1930s-1950s). Documentary sources from the Central State Archive of the October Revolution, the Higher Bodies of State Power and Administration of the USSR (TsGaOR). Part 1. Moscow. (In Russian).

Smirnova, T. B. (2005). Interethnic Processes among Russian Germans in Western Siberia. In Russian Germans in a Foreign Environment: Problems of Adaptation, Mutual Influence, and Tolerance (pp. 203-212). Moscow: MSNK-Press. (In Russian).

Smirnova, T. B., \& Kisser, T. S. (2017). The diversity of Germans in Russia. Ural Historical Bulletin, (2), 44-53. (In Russian).

Stefanenko, T. G., Tumgoeva, T. A., \& Kotova, M. V. (2017). Cultural Memory and Social Identity of the Ingush as Representatives of the Repressed People. National fournal of Psychology, (4), 45-56. doi: 10.11621/npj.2017.0404 (In Russian).

Svirina, D. V. (2018). Memories of the Deportation of the Volga Germans: Main Narrative and Motives (on the Materials of the Krasnoyarsk Territory). Bulletin of Tomsk State University, (51), 157-163. doi: 10.17223/19988613/51/22 (In Russian).

The 1989 All-Union Population Census. Ethnic composition of the population by republics of the USSR. (2011, June 4). Retrieved from Demoscope Weekly website: http:// www.demoscope.ru/weekly/ssp/sng_nac_89.php?reg=0 (In Russian).

The first general census of the Russian Empire in 1897. Distribution of population by native language, provinces and regions. (2005). Retrieved from Demoscope Weekly website: http://www.demoscope.ru/weekly/ssp/rus_lan_97.php?reg=0 (In Russian).

Vaschkau, N. E. (1994). Germans in Russia: History and Fate. Volgograd: Volgograd State University Press. (In Russian).

Wolter, G. A. (1998). The Zone of Full Rest: Russian Germans during and after the War. Moscow: Varyag. (In Russian).

Wormsbecher, A. (1993). In the Siberian hinterland. Moscow: Septima. (In Russian).

Yakovlev, Y. A. (2020, March 3). Soviet Germans - "punished people" (typical fate of the Siberian German woman Florentina Sauer). Part 1. Retrieved from Sibiryaks, Free and Involuntary website: https://xn--90anbaj9ad0j.xn--80asehdb/documents/ sovetskie-nemcy-nakazannyj-narod-tipichnaya-sudba-sibirskoj-nemki-florentinyzauer-chast-1/ (In Russian). 